\title{
Impact of UVA radiation on algae and bacteria in Baltic Sea ice
}

\author{
Jonna Piiparinen ${ }^{1,2, *}$, Harri Kuosa ${ }^{2}$ \\ ${ }^{1}$ Finnish Environment Institute, Marine Research Centre, PO Box 140, 00251 Helsinki, Finland \\ ${ }^{2}$ Tvärminne Zoological Station, University of Helsinki, J.A. Palménin tie 260, 10900 Hanko, Finland
}

\begin{abstract}
The effects of solar UVA radiation on total bacterial production $\left({ }^{3} \mathrm{H}\right.$-thymidine [TTI] and ${ }^{14} \mathrm{C}$-leucine [TLI] incorporation), bacterial numbers, chlorophyll $a$, algal biomass and photosynthesisirradiance (P-E) response curves in Baltic Sea land-fast ice were studied in situ in the Gulf of Finland in March 2005. Two tent-shaped frames, one covered with UVR opaque foil (exposure to photosynthetically active radiation [PAR]) and the other with UVA transparent foil (exposure to PAR+UVA), were set up on snow-free sea ice. The ice was incubated for $21 \mathrm{~d}$, and weekly samples were taken from both treated and snow-covered untreated (UNT) ice. The exposure to incident PAR controlled the algal biomass but exposure to UVA caused an additional decrease in biomass (mean UNT, $47 \mu \mathrm{g}$ $\mathrm{C} \mathrm{l}^{-1}$; PAR, $38 \mu \mathrm{g} \mathrm{C} \mathrm{l}^{-1}$; PAR+UVA, $18 \mu \mathrm{g} \mathrm{C} \mathrm{l}^{-1}$ ). Unidentified flagellates $<20 \mu \mathrm{m}$ were more sensitive to PAR than to UVA, whereas the other algal groups were more sensitive to UVA (chlorophytes, pennate diatoms) or mutually sensitive to PAR and UVA (centric diatoms). In the top $10 \mathrm{~cm}$, the higher values of photosynthetic parameters $\left(\alpha^{\mathrm{b}}\right.$ and $\left.P_{\mathrm{m}}^{\mathrm{b}}\right)$ in the PAR+UVA compared with the PAR treatment reflected the differences in the algal community composition. The effects of UVA on bacterial production were mainly limited to the top $5 \mathrm{~cm}$ and were linked to changes not only in algal biomass but also in algal species composition. After the first incubation week, the TLI:TTI ratios in the clearly flagellate-dominated surface layers (UNT, PAR+UVA) were higher than in the PAR treatment, where the increase in TTI was attributed to the marked increase in chlorophyte and pennate diatom biomass. These results show that the responses of Baltic sea-ice organisms must be taken into account when the effects of climate change are assessed.
\end{abstract}

KEY WORDS: UVA $\cdot$ Sea ice $\cdot$ Bacterial production $\cdot$ Algae $\cdot$ Baltic Sea

\section{INTRODUCTION}

The ozone depletion in the stratosphere has stimulated scientists from various fields to study ultraviolet radiation (UVR; 280 to $400 \mathrm{~nm}$ ), especially the UVB component (280 to $315 \mathrm{~nm}$ ), and its effects on living organisms. Whereas the intensity and spectral quality of UVB reaching the biosphere are strongly dependent on the stratospheric ozone levels, the portion of UVA (315 to $400 \mathrm{~nm}$ ) in the incoming solar radiation is more stable. Because it covers a wider wavelength span than UVB, UVA can cause more damage to cells despite its lower energy content per photon (Helbling et al. 1995, Holm-Hansen 1997, Sommaruga et al. 1997).

In organisms, the non-DNA chromophores (such as riboflavine) and unsaturated lipids play central roles by absorbing UVA and transferring the excitation energy directly to DNA or to molecular oxygen, creating reactive oxygen species (ROS), which in turn cause oxidative damage to organic molecules like DNA (Harm 1980, Jagger 1985, Peak \& Peak 1986). UVA has also been shown to shut down net RNA synthesis and to damage cell membranes and proteins (Jagger 1985, Peak \& Peak 1986). In the chloroplasts of algae, the absorption of excessive photosynthetically active radiation (PAR) and UVA oversaturates the photosynthetic electron transport chain and chlorophyll becomes an alternative electron acceptor, leading to the formation of ROS if oxygen is present (Asada \& Takahashi 1987, Salin 1988). The reaction centre of the photosystem II (PSII) protein-pigment complex and enzymes from 
the Calvin cycle are highly sensitive to ROS and, thus, photosynthesis generally becomes inhibited under UVR exposure.

The small size of single-celled organisms makes them particularly susceptible to UVR because the radiation quickly reaches most of the cellular components (Garcia-Pichel 1994, Karentz et al. 1994, Jeffrey et al. 1996). Bacteria, as well as algae, are known to be able to repair some of the UVR-related damages in DNA via photoreactivation, excision repair and postreplication repair (Harm 1980, Karentz 1994). The extent of the repair processes varies widely between species and even within strains, but it is also dependent on the wavelength in the UV region (Harm 1980, Jagger 1985). In addition, algae are known to synthesize intra- and extracellular UV-absorbing compounds like mycosporine-like amino acids (MAAs), which have their absorption maxima between 309 and $360 \mathrm{~nm}$ (Roy 2000 and references therein). In Antarctic ice algae, porphyra-334 is the predominant MAA compound (Karentz 1994, Ryan et al. 2002) but shinorine, mycosporine-glycine and palythine have been identified from Ross Sea and Baltic Sea ice samples (Erickson 2000 in Arrigo \& Thomas 2004, Uusikivi et al. 2010). However, the results of Ryan et al. (2002) indicated that the photoprotective role of MAAs may not be as important in sea-ice algae (mainly diatoms) as in phytoplankton (Villafañe et al. 1995). In contrast to algae, heterotrophic bacteria generally lack UVprotective pigments and compounds (Garcia-Pichel 1994, Karentz 1994).

The sensitivity to UVR generally increases with latitude (Vernet 2000 and references therein). In Antarctica, UVA had a greater photoinhibitory effect on photosynthesis compared with UVB (30 and 14\%, respectively) (see Holm-Hansen 1997); a similar trend was observed in bacterioplankton viability, with UVA being responsible for a ca. $52 \%$ reduction in the survival fraction compared with $14 \%$ for UVB (Helbling et al. 1995). In the surface layers of an alpine lake and the northern Adriatic Sea, the $70 \%$ inhibition in bacterial production was due equally to UVA and PAR whereas UVB had no effect (Sommaruga et al. 1997). In sea ice, the very limited possibility for vertical movement and the general dark-adaptation of the organisms may make them more susceptible to UVR compared with plankton. The extracellular formation of ROS in the brine channels may cause additional damage to the cells (Neftel et al. 1984). Previous studies on sea-ice organisms have so far only focused on UVB or UVR; the role of UVA in causing UVR damage has not yet been determined.

Sea ice is formed in the Baltic Sea annually and the ice-covered period can last up to 6 mo in the northern areas (Mälkki \& Tamsalu 1985). Despite the low sur- face salinity of the northern Baltic Sea (PSU $\leq 7$ ), brine channels hosting active microbial food webs are found in the Baltic Sea ice (Norrman \& Andersson 1994, Meiners et al. 2002, Kaartokallio 2004), and the icealgal biomass is manifold compared to the phytoplankton biomass in the underlying water column (Haecky et al. 1998, Meiners et al. 2002, Kaartokallio et al. 2007, Rintala et al. 2010). Bacteria in polar sea ice have been reported to be more active (27 to $34 \%, 5$-cyano-2,3ditolyl tetrazolium chloride stained) than bacteria in the water column (1 to $10 \%$ ) (Junge et al. 2002, Martin et al. 2008); a similar result was obtained from the Baltic Sea (J. Piiparinen unpubl. data).

The penetration and effects of UVR in sea ice depend on snow and ice thickness, but impurities (biota, particulates, dissolved organics) as well as air bubbles and brine pockets also have an effect by absorbing and scattering light (Perovich 1998). Compared with the polar sea ice, the snow layer on the Baltic Sea ice is relatively thin with high spatial and temporal variation in presence, thickness and density. The fluctuating air temperatures result in meltingfreezing events in the Baltic Sea, exposing the ice to solar radiation and incorporating the melted snow into superimposed ice (Granskog et al. 2006, Pirazzini et al. 2006). Rasmus et al. (2002) calculated that transmittance of UVA was from ca. 5 to $11 \%$ for $30 \mathrm{~cm}$ thick ice with $3 \mathrm{~cm}$ snow cover in Santala Bay, Gulf of Finland, in early April. Several measurements carried out at the same location in March by Ehn et al. (2004) showed that transmittance of UVA in $27.5 \mathrm{~cm}$ thick snow-free ice can be as high as $30 \%$.

In light of future climate scenarios with milder winters, i.e. thinner snow and ice cover in the Baltic Sea (Haapala et al. 2001, HELCOM 2007), this study aimed to investigate in situ the long-term effects of solar UVA radiation on bacterial productivity, algal biomass and composition of natural sea-ice algal communities in snow-free conditions. The in situ approach was chosen because of its minimal disturbance on the studied community, which is of major importance when working with sea ice.

\section{MATERIALS AND METHODS}

Study site, experimental set-up and sampling. This study was carried out on fast ice in the vicinity of the Tvärminne Zoological Station of the SW coast of Finland (59 51' N, 23 16' E) during March and April 2005. The experimental units consisted of 2 tent-shaped wooden frames covered with transparent plastic foils, each frame covering an area of $0.97 \mathrm{~m}^{2}$. This area is equal to approximately 100 ice cores and thus provided an area large enough for random sampling of the 
$\leq 11$ ice cores per treatment required during the experiment. To serve as the UVA exposure treatment (PAR+UVA), one frame was covered with a plastic foil (Roscolab Ltd.), which blocked UVB and allowed, on average, $85 \%$ transmission of wavelengths $>315 \mathrm{~nm}$. The UVA exclusion treatment (PAR) was achieved by covering the other frame with a UVR opaque foil (Roscolab Ltd.), which transmitted nothing below $390 \mathrm{~nm}$ but allowed, on average, $82 \%$ transmission of visible wavelengths. The transmittance spectrum of the foils was measured with a Perkin Elmer Lambda 650 UV/VIS spectrometer and verified in field conditions with a Ramses-ACC Hyperspectral Irradiance Sensor (320 to $950 \mathrm{~nm}$ ).

The frames were anchored onto snow-free sea ice at a site with minimum shading from nearby land and at a water depth of $3.5 \mathrm{~m}$. The foils were cleared every morning from the frost formed during the night. Air temperature and global radiation (400 to $1100 \mathrm{~nm}$ ) during the experiment were measured every $30 \mathrm{~min}$ by the GroWeather station at the Tvärminne Zoological Station. Snow depth on the untreated ice was measured with a precision of $1 \mathrm{~cm}$ on each sampling date.

Ice samples from the treated ice (PAR+UVA and PAR) were taken every $7 \mathrm{~d}$ from 2 March to 6 April 2005, with one extra sampling after 4 d incubation. To assess the simultaneous natural succession and the effect of the tent enclosures, the snow-covered untreated ice near the experimental units (UNT) was also sampled at each sampling. In order to ensure a sufficient amount of ice for the planned analyses, 2 to 3 ice cores from both treatments and untreated ice were drilled with a Kovacs Mark II ice auger. The ice cores were cut into 3 to 4 vertical pieces depending on the ice thickness, but always so that the uppermost ice was cut into pieces at intervals of $5 \mathrm{~cm}$. Samples were placed in plastic containers and taken to the laboratory for further processing. One part from each sample was used for bacterial production measurement (see below) and the rest was melted in darkness at $+4^{\circ} \mathrm{C}$. After thawing, the parallel samples were pooled and mixed, salinities were measured using a YSI 63 meter and subsamples were drawn for further analyses.

Chlorophyll a and algal biomass. Chlorophyll a (chl a) was determined by filtering two $100 \mathrm{ml}$ aliquots from each thawed sample onto Whatman GF/F filters, which were immediately placed in $96 \% \mathrm{v} / \mathrm{v}$ ethanol and frozen $\left(-18^{\circ} \mathrm{C}\right)$ for $30 \mathrm{~d}$ at most. Before measuring, the samples were extracted at room temperature in darkness for $24 \mathrm{~h}$. The extract was filtered again through a Whatman GF/F filter and the chl a fluorescence was measured with a Jasco FP 750 spectrofluorometer calibrated with pure chl a (SigmaAldrich); concentrations were calculated according to HELCOM (1988).
Algal species abundance and biomass were determined at the beginning of the experiment and after $3 \mathrm{wk}$ incubation for the whole-ice columns and every week for the top $5 \mathrm{~cm}$. A volume of $50 \mathrm{ml}$ of each melted sample, preserved with acid Lugol's solution, was settled according to Utermöhl (1958) and the algae were counted using a Leica DM IRB microscope. Due to the low salinity of Baltic Sea ice, the direct melting does not generally produce serious problems in most algal groups, but some fragile flagellates may be lost (H. Kuosa unpubl. data). Thirty to sixty cells or colonies/trichomes of the most abundant taxa were counted either using a $10 \times$ or $40 \times$ objective, depending on the size of the taxon. The counted area varied from half of the cuvette for large taxa and colonies/trichomes to 20 random fields for small numerous taxa.

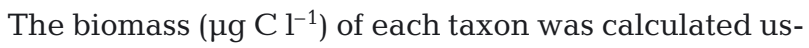
ing taxon-specific cell-size-dependent carbon contents (Menden-Deuer \& Lessard 2000, HELCOM 2006). The biomass diversity in samples was assessed by calculating Simpson's index of diversity $(1-D)$ for each sample.

Photosynthesis-irradiance responses. The photosynthesis-irradiance response (P-E) curves (Platt et al. 1980) were determined at the start (2 March), after $4 \mathrm{~d}$ incubation (6 March) and after 3 wk incubation (23 March). Melted pooled ice samples (3 ml) were incubated with $\mathrm{NaH}^{14} \mathrm{CO}_{3}$-addition (final concentration $0.33 \mu \mathrm{Ci} \mathrm{ml}{ }^{-1}$ ) (International Agency for ${ }^{14} \mathrm{C}$, DHI) for $2 \mathrm{~h}$ under 16 different light intensities up to $577 \mu \mathrm{E} \mathrm{m} \mathrm{m}^{-2}$ $\mathrm{s}^{-1}$ and 2 dark replicates in incubators equipped with quartz halogen lamps (GE ELH, 120 V 300 W), heat shields and a green filter for use in the Baltic Sea, resulting in a spectrum from 450 to $680 \mathrm{~nm}$ with a maximum intensity at $540 \mathrm{~nm}$. The incubators were cooled by circulating ice-cold water through them. The incubations were terminated by adding $100 \mu$ of formaldehyde (final concentration $1.23 \%$ ) to the samples. The unincorporated $\mathrm{NaH}^{14} \mathrm{CO}_{3}$ was removed by acidifying samples with $1 \mathrm{~N} \mathrm{HCl}$ for $48 \mathrm{~h}$, after which Insta-Gel Plus scintillation cocktail (Perkin Elmer) was added and the incorporated radioactivity was measured using a Wallac WinSpectral 1414 scintillation counter. The photosynthetic rates (mg C $\mathrm{C}^{-1} \mathrm{~h}^{-1}$ ) were calculated according to Steemann-Nielsen (1952) and corrected with the carbon isotope discrimination (1.05). The total inorganic carbon (TIC) concentrations were obtained from a linear relationship between bulk ice salinity and TIC concentration $\left(\mathrm{R}^{2}=0.88, \mathrm{n}=50 ; \mathrm{H}\right.$. Kuosa unpubl. data). The rates were normalized to $\mathrm{chl}$ a $(\mathrm{mg} \mathrm{C} \mathrm{mg}$ $\operatorname{chl} a^{-1} \mathrm{~h}^{-1}$ ), and photosynthetic efficiency $\left(\alpha^{\mathrm{b}}\right)$, maximum capacity $\left(P_{\mathrm{m}}^{\mathrm{b}}\right)$ and light saturation index $\left(E_{\mathrm{k}}\right)$ were determined from the P-E curves using the equations of Platt et al. (1980). Previous tests (Kaartokallio 2004) in the study area indicate that directly melted samples can be used for ${ }^{14} \mathrm{C}$-uptake measurements. 
Bacterial number. To determine the total bacterial number (TBN), $20 \mathrm{ml}$ was drawn from each pooled and thawed sample and preserved with EM-grade glutaraldehyde (final concentration $1.25 \%$ ). Aliquots of $5 \mathrm{ml}$ were filtered onto black $0.2 \mu \mathrm{m}$ pore-sized polycarbonate filters (Osmonics) and stained for 5 min with $0.055 \%$ acridine orange solution (Hobbie et al. 1977). Bacteria were counted under blue excitation light (I3 filter block) using a Leitz Aristoplan epifluorescence microscope equipped with a PL Fluotar 100× 12.5/20 oil immersion objective. At least 200 cells from 20 random fields in a New Porton E11 counting grid were counted from each sample.

${ }^{3} \mathbf{H}$-thymidine and ${ }^{14} \mathbf{C}$-leucine incorporation. The effect of UVA on bacterial production was assessed by measuring the total ${ }^{3} \mathrm{H}$-thymidine (TTI) and ${ }^{14} \mathrm{C}$-leucine (TLI) incorporation (Fuhrman \& Azam 1982, Kirchman et al. 1985). The dual-label approach was chosen to detect the balance/imbalance in bacterial growth and the sensitivity of DNA and protein synthesis to UVA, as these processes may respond differently to different wavelengths (Simon 1990, Aas et al. 1996, Sommaruga et al. 1997). The incorporation rates were not converted to carbon production, as it was not relevant for this study and the calculation would have required knowledge on several conversion factors not well known in this highly variable experimental environment. In order to avoid rapid melting and drainage of brine, the following procedures were performed at $+4^{\circ} \mathrm{C}$. After cutting the ice (see above), a piece of each parallel ice sample was crushed, first coarsely with a spike and then with an electric ice crusher. Approximately $7.5 \mathrm{~g}$ of pooled crushed ice samples was weighed in a scintillation vial using a Mettler PE 3600 laboratory balance, after which $2 \mathrm{ml}$ of $0.2 \mu \mathrm{m}$ filtered autoclaved Baltic Sea water concentrated by evaporation to 12.9 (ca. $2 \times$ seawater salinity at the study site) was added to simulate brine salinity and ensure even distribution of labelled thymidine and leucine (Kaartokallio 2004). After that, the adsorption blank was fixed with formaldehyde (final concentration $1.85 \%$ ) and [methyl- ${ }^{3} \mathrm{H}$ ]-thymidine and $\mathrm{L}-\left[{ }^{14} \mathrm{C}(\mathrm{U})\right]$-leucine (Perkin Elmer) were added to all samples ( 2 to 3 replicates per sample) in final concentrations of 14 and $1000 \mathrm{nM}$, respectively. These concentrations are based on the results of several earlier saturation-level tests in sea ice from the same area at different stages of the ice season (Kaartokallio 2004, Kuosa 2006, J. Piiparinen unpubl.). The labelled leucine was diluted 1:4 with carrier leucine, except for the 2 first samplings when only labelled leucine was added. The samples were incubated in the dark at ca. $-0.5^{\circ} \mathrm{C}$ in an LMS 250 cooled incubator. At sub-zero temperatures bacterial processes are slow and thus, the incubation time was prolonged to $16-17 \mathrm{~h}$. The incubation was stopped by adding formaldehyde (final con- centration $1.85 \%$ ) and samples were allowed to melt. The standard cold-trichloroacetic acid extraction method (Fuhrman \& Azam 1982) was used for the removal of unincorporated ${ }^{3} \mathrm{H}$-thymidine and ${ }^{14} \mathrm{C}$ leucine. The samples were filtered onto 0.2 $\mu \mathrm{m}$ MCEfilters (Advantec), which were then dissolved with Insta-Gel Plus scintillation cocktail in scintillation vials. The radioactivity was measured using a Wallac WinSpectral 1414 scintillation counter.

Statistical analysis. Multiple regression analysis was used to test the significance of the differences between treatments. Untreated ice was excluded from the analysis because of the difference in the incident light spectrum. Variation of chl $a$, TTI, TLI and TBN (dependent variables) was modelled using global cumulative radiation (GR) at the surface (proxy for UVA radiation) and bulk salinity (standardization for salinity difference) as independent variables. The different treatments (PAR+UVA and PAR) were included in the model with the dummy variable technique (Draper \& Smith 1981). The insignificant independent variables for the model of each dependent variable were eliminated with a backward regression technique (probability of $F$ to remove: 0.10 ). The regression analyses were run for each layer separately and the bottommost layer was run in the same regression analysis independent of the ice thickness, as it always represented the newly formed ice. The treatments differed significantly if the dummy variable and/or the cross-product term of GR and the dummy variable were significant for the model. All the procedures were performed in SPSS for Windows release 15.0. Values are presented as means $\pm \mathrm{SD}$ unless otherwise indicated.

\section{RESULTS}

\section{Physical environment}

The winter of 2005 was moderate, judging by the ice extent of the Baltic Sea, according to the data of the Finnish Institute of Marine Research (www.itameriportaali.fi/en/tietoa/jaa/jaatalvi/en_GB/2005/). A mild period in December-January melted the first ice, which had formed in November. The freezing began again in February, and the ice was ca. 2 wk old when the experiment began. The untreated ice reached its maximum thickness of $29 \mathrm{~cm}$ at the end of March, whereas both experimental fields started to melt down $1 \mathrm{wk}$ earlier because of the greenhouse effect of the experimental units; thus, the 2 last samplings (30 March and 6 April 2005) were excluded from the final data analysis (Fig. 1B). After 2 wk of incubation, the greenhouse effect started to gradually decrease the bulk salinities in the top $5 \mathrm{~cm}$, and on March 23 the 

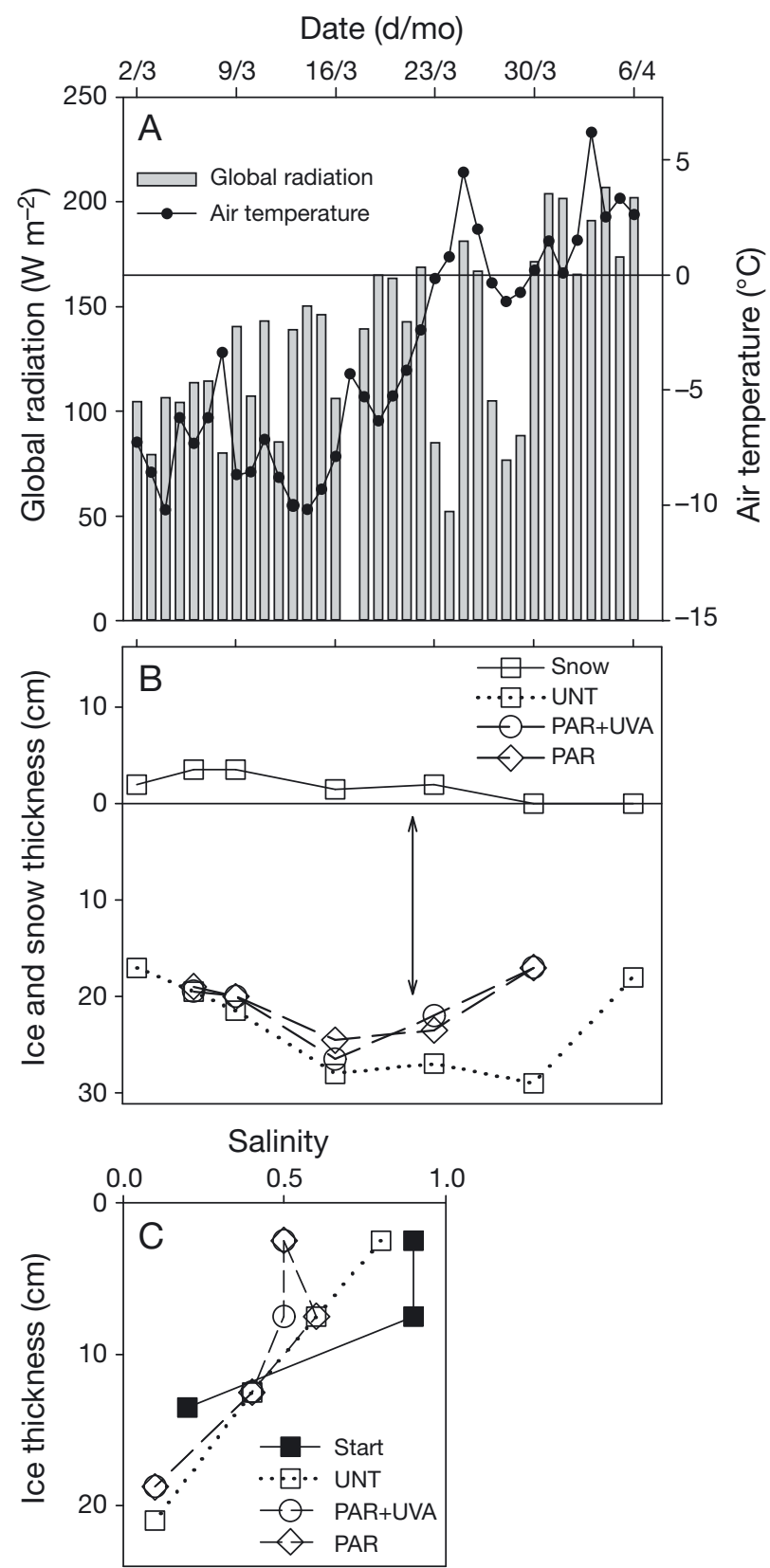

Fig. 1. (A) Daily averages of global radiation (400 to $1100 \mathrm{~nm}$ ) and air temperature at the study site. Horizontal line denotes $0^{\circ} \mathrm{C}$. (B) The ice thickness of untreated (UNT) and treated (PAR+UVA and PAR) ice during the experiment. The thickness of the snow layer on the untreated ice (snow) is shown above the reference line denoting the snow-ice interface. Samples taken after 23 March 2005 (marked with an arrow) were excluded from the data analysis (see 'Results': Physical environment' for details). (C) Bulk ice salinity profiles at the beginning (start) and after $3 \mathrm{wk}$ of incubation (dashed/ dotted lines with open symbols)

salinities in the treated ice were 0.3 units lower than in the untreated ice (Fig. 1C). During the $3 \mathrm{wk}$ of incubation, the untreated ice was always covered with packed dry snow $(2.5 \pm 0.9 \mathrm{~cm})$. At every sampling, a
$0.5 \mathrm{~m}$ thick low salinity layer $(1.3 \pm 0.5)$ was observed beneath the ice, overlaying the saltier Baltic Sea water of $4.8 \pm 0.4$. The solar radiation (400 to $1100 \mathrm{~nm}$ ) more than doubled during the experiment (Fig. 1A). No instrumentation was available to measure solar UVA radiation continuously at the study site but, as the portion of UVA in the solar radiation is known to be constant, it can be approximated that UVA radiation had a similar increasing trend. This was supported by the significant correlation (Spearman's $\rho=0.94, \mathrm{n}=728$ ) between global radiation (335 to $2200 \mathrm{~nm}$ ) and UV radiation (290 to $400 \mathrm{~nm}$ ) measured at a monitoring station $100 \mathrm{~km}$ west of Tvärminne in March (data provided by Finnish Meteorological Institute). The performance of the foils in the field was tested in a separate experiment, and the spectral attenuation profiles inside the treated ice differed only in UVA (J. Piiparinen et al. unpubl.).

\section{Regression analysis}

The regression analyses resulted in 12 multiple regression models with varying independent variables. The cross-product term was significant for every model except TBN, which depended only on bulk salinity in the top $10 \mathrm{~cm}$; in the bottommost layer no regression model could be fit to TBN (Table 1). The significant cross-product term shows that GR was significant for the regression function of PAR treatment but not for the PAR+UVA function and, thus, the coefficients were different for the 2 treatments. Salinity was significant for all the regression models in the top $10 \mathrm{~cm}$, but below $10 \mathrm{~cm}$ the cross-product term (for TTI, TLI and chl a) and GR (for TTI and TLI) were the only significant independent variables.

\section{Effects on chl $a$ and algal biomass}

At the beginning of the experiment, chl a was evenly distributed throughout the ice column. In the untreated

Table 1. Statistically significant differences between PAR+ UVA and PAR treatments in each layer. The results were based on 12 different multiple regression models run for each layer $(\mathrm{n}=10)$ (data not shown). $\mathrm{R}^{2}$-values measuring the goodness-of-fit of the models are shown. TBN: total bacterial number; TLI: total ${ }^{14} \mathrm{C}$-leucine incorporation; TTI: total ${ }^{3} \mathrm{H}$-thymidine incorporation. ${ }^{*}: \mathrm{p}<0.05$

\begin{tabular}{|lcccc|}
\hline Depth $(\mathrm{cm})$ & Chl $a$ & TTI & TLI & TBN \\
\hline $0-5$ & $0.86^{*}$ & $0.92^{*}$ & $0.90^{*}$ & 0.46 \\
$5-10$ & $0.89^{*}$ & $0.97^{*}$ & $0.94^{*}$ & 0.65 \\
$>10$ & $0.78^{*}$ & $0.80^{*}$ & $0.81^{*}$ & 0.00 \\
\hline
\end{tabular}


ice, the increase in chl a concentration was most marked in the top $5 \mathrm{~cm}$ where it increased from 0.7 to $6.5 \mu \mathrm{g}^{-1}$ in $3 \mathrm{wk}$. The chl a distribution in the PAR treatment was generally similar to the untreated ice, but the concentrations in the PAR treatment were significantly lower in the top $10 \mathrm{~cm}\left(\mathrm{R}^{2}=0.81, \mathrm{p}=0.034\right)$ (Fig. 2A). Exposure to UVA kept the chl a concentrations close to the starting values, leading to a some-

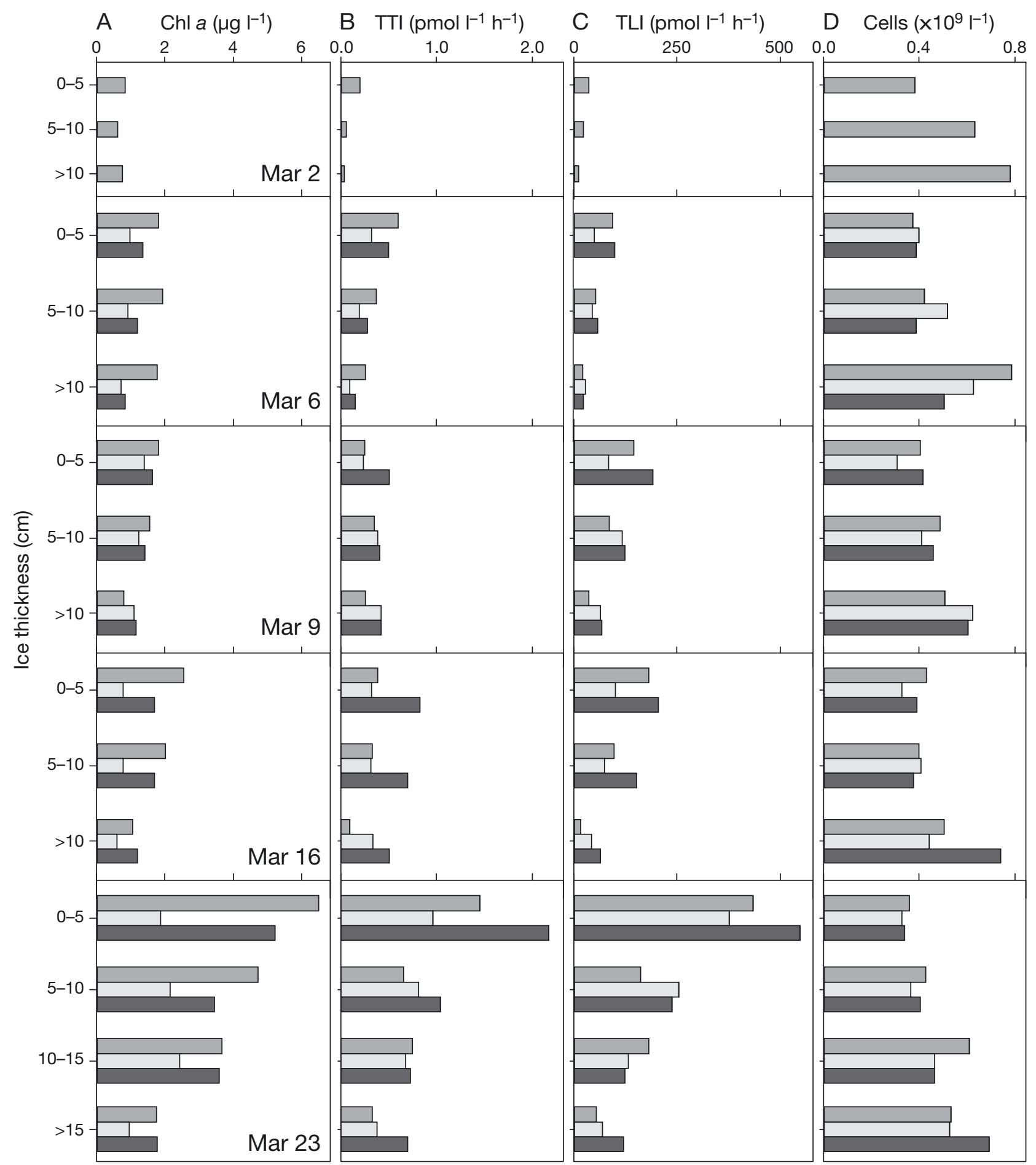

Fig. 2. (A) Chlorophyll a (chl a) concentrations, (B) total ${ }^{3} \mathrm{H}$-thymidine incorporation (TTI) rate, (C) total ${ }^{14} \mathrm{C}$-leucine incorporation (TLI) rate, and (D) total bacterial number (TBN) in the untreated ice (medium-grey bars), PAR+UVA (light-grey bars) and PAR (dark-grey bars) treatments 
what different chl a distribution across the layers and resulting in significantly lower chl a values compared with the PAR treatment (Fig. 2A, Table 1).

The mean algal biomass in the untreated ice increased from 7 to $47 \mu \mathrm{g} \mathrm{C} \mathrm{l}^{-1}$ in $3 \mathrm{wk}$. The corresponding biomass in the PAR treatment $\left(38 \mu \mathrm{g} \mathrm{C}^{-1}\right)$ was lower than in UNT, but the exposure to UVA dropped the biomass further by half (Fig. 3). The algal species composition and their distribution changed markedly in the treatments, with the changes beginning to show after $1 \mathrm{wk}$ of incubation (data not shown) with a coincident increase in the solar irradiance. Unidentified flagellates $<20 \mu \mathrm{m}$ dominated the icealgal densities and biomass in almost every sample but their mean biomass in the PAR and PAR+UVA treatments was approximately half and one-third of that in the untreated ice, respectively. Chlorophytes and pennate diatoms were the 2 main groups to benefit from the exclusion of UVA, and their biomasses declined with depth (Fig. 3). The unidentified colonial species with small coccoid cells were by far the most abundant chlorophytes in single-cell number, but larger, flagellated Chlamydomonas spp. dominated the chlorophyte biomass. In contrast to chlorophytes, both the abundance and biomass of pennate diatoms were dominated by the same species group, the unidentified diatoms (20 to $30 \mu \mathrm{m})$, in both treatments. The pennate diatom Achnanthes taeniata was present in layers below $10 \mathrm{~cm}$ in both treated and untreated ice. The mean biomass of centric diatoms varied only slightly (0.6 to $3.5 \mu \mathrm{g} \mathrm{C}^{-1}$ ), but their distribution was markedly different in the treated and untreated ice. In both treatments, the centric diatom biomass peak occurred in the 10 to $15 \mathrm{~cm}$ layer whereas in the untreated ice the highest biomass was observed in the topmost $5 \mathrm{~cm}$ (Fig. 3). The centric species were mostly Chaetoceros wighamii and occasionally also Melosira arctica and Thalassiosira baltica. The 2 latter species and cryptophytes were absent from the PAR+UVA samples, but they were encountered in the PAR treatment and untreated ice.

The difference in the biomass-based Simpson's index of diversity between treatments was largest in the topmost layer (PAR+UVA, 0.44; PAR, 0.76), and in the layers below values varied from 0.53 to 0.79 independently of UVA. The corresponding surface ice value in the untreated ice (0.63) fell between the values of the treatments, but otherwise the values were lower than in the treated ice $(0.15$ to 0.44$)$.

\section{Photosynthetic activity}

The highest $P_{\mathrm{m}}^{\mathrm{b}}$ in the untreated ice was always observed in the surface layer, whereas the layer with

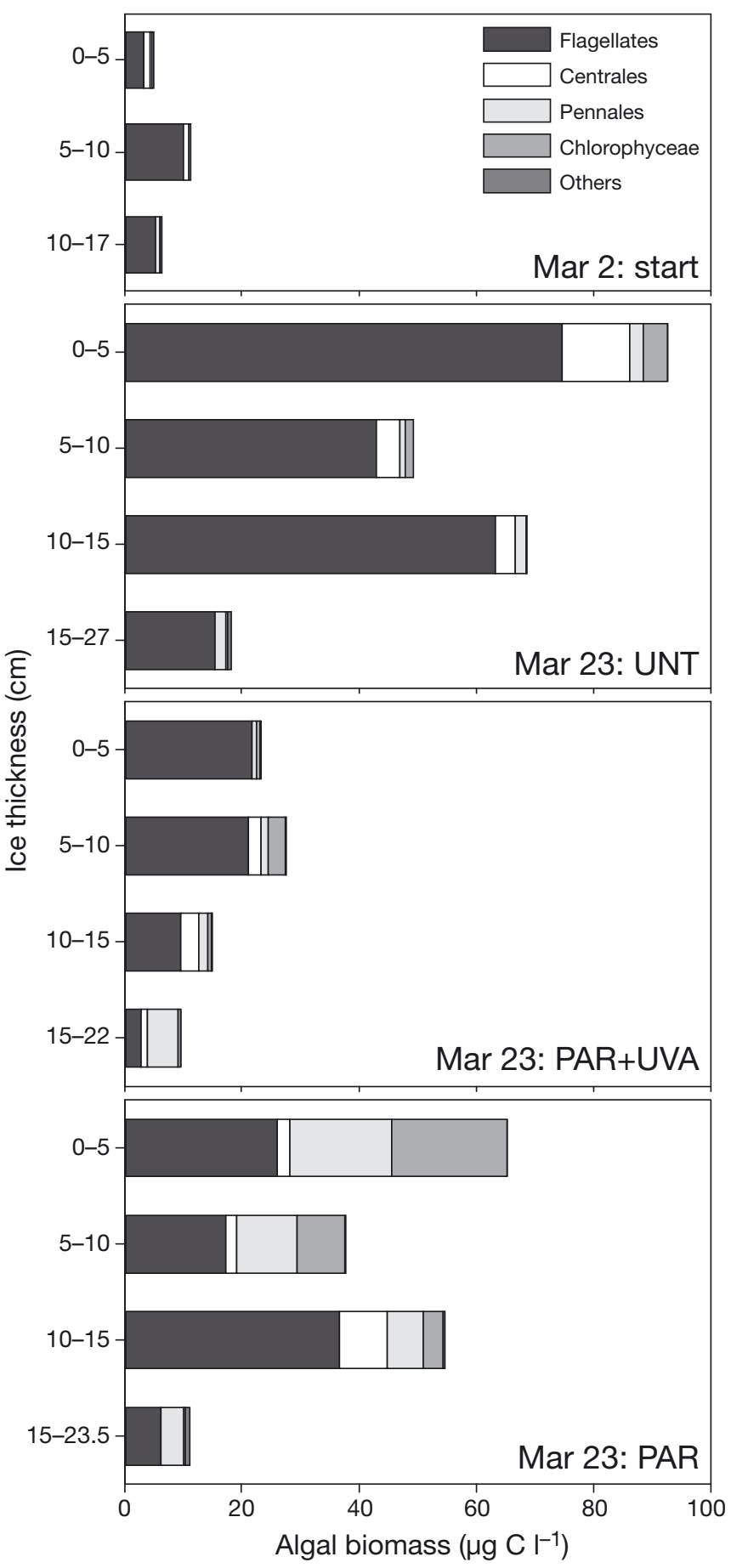

Fig. 3. Biomass of the main algal groups at the start of the experiment and after $3 \mathrm{wk}$ incubation in the untreated (UNT) and treated (PAR+UVA, PAR) ice. Others: cyanophytes, cryptophytes and dinoflagellates

the highest $\alpha$-value changed from surface to bottom during the experiment (Table 2). At the end of the experiment, the mean values of $\alpha^{\mathrm{b}}$ and $P_{\mathrm{m}}^{\mathrm{b}}$ in the treated ice were lower and, moreover, were lower in the PAR 
$\left(\alpha^{\mathrm{b}}=0.0047, P_{\mathrm{m}}^{\mathrm{b}}=0.62\right)$ than in the PAR+UVA $\left(\alpha^{\mathrm{b}}=\right.$ $0.0058, P_{\mathrm{m}}^{\mathrm{b}}=0.77$ ) treatment. The biggest differences between the 2 treatments were in the surface layers, whereas the P-E curves in layers below $10 \mathrm{~cm}$ were

Table 2. Photosynthetic parameters and $\mathrm{R}^{2}$-values of the fitted models at the start and end of the experiment. $P^{\mathrm{b}}$ : maximum photosynthetic capacity ( $\mu \mathrm{g} \mathrm{C}[\mu \mathrm{g} \mathrm{chl} \mathrm{a}]^{-1} \mathrm{~h}^{-1}$ ); $\alpha^{\mathrm{b}}$ : photo-

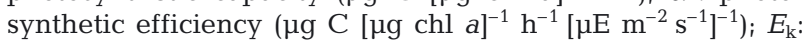
light saturation index $\left(\mu \mathrm{E} \mathrm{m} \mathrm{m}^{-2} \mathrm{~s}^{-1}\right)$. UNT: snow-covered untreated ice; PAR+UVA: photosynthetically active radiation (PAR) and UVA exposure; PAR: UVA exclusion (PAR)

\begin{tabular}{|lccccc|}
\hline & $\begin{array}{c}\text { Depth } \\
(\mathrm{cm})\end{array}$ & $\alpha^{\mathrm{b}}$ & $P^{\mathrm{b}}{ }_{\mathrm{m}}$ & $E_{\mathrm{k}}$ & $\mathrm{R}^{2}$ \\
\hline 2 March 2005 & & & & & \\
UNT & $0-5$ & 0.0072 & 0.91 & 126 & 0.97 \\
& $5-10$ & 0.0069 & 0.71 & 102 & 0.97 \\
& $10-17$ & 0.0066 & 0.36 & 55 & 0.90 \\
23 March 2005 & & & & & \\
UNT & $0-5$ & 0.0076 & 0.85 & 112 & 1.00 \\
& $5-10$ & 0.0032 & 0.49 & 153 & 0.99 \\
& $10-15$ & 0.0088 & 0.59 & 67 & 0.95 \\
PAR+UVA & $15-27$ & 0.0101 & 0.68 & 67 & 0.98 \\
& $0-5$ & 0.0069 & 0.81 & 117 & 0.98 \\
& $5-10$ & 0.0079 & 1.08 & 137 & 0.98 \\
PAR & $10-15$ & 0.0045 & 0.67 & 148 & 0.95 \\
& $15-22$ & 0.0043 & 0.60 & 140 & 0.94 \\
& $0-5$ & 0.0037 & 0.73 & 197 & 0.98 \\
& $5-10$ & 0.0054 & 0.61 & 113 & 0.99 \\
& $10-15$ & 0.0039 & 0.66 & 169 & 0.99 \\
& $15-23.5$ & 0.0053 & 0.54 & 101 & 0.94 \\
\hline
\end{tabular}

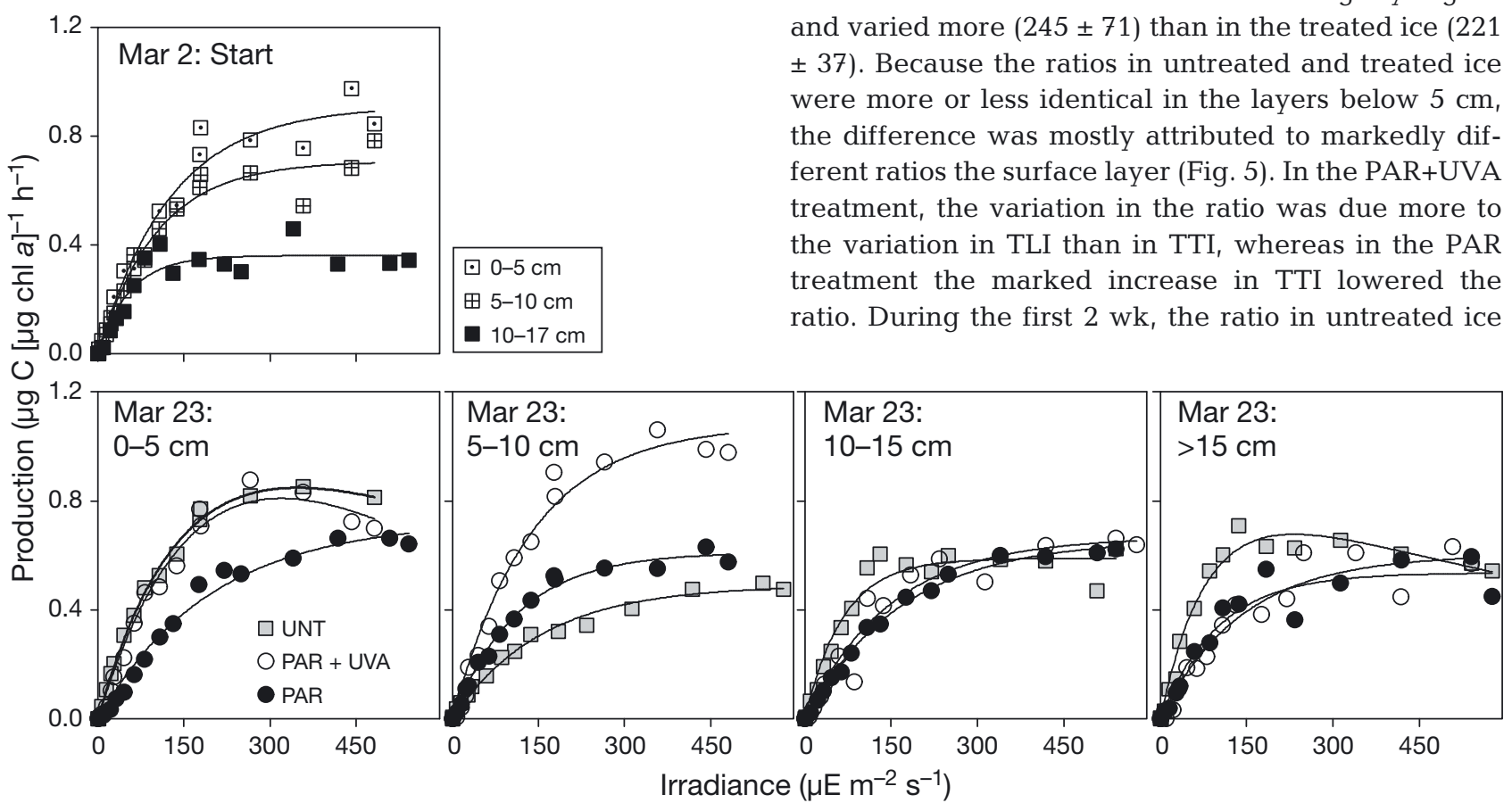

Fig. 4. Photosynthetic-irradiance (P-E) response curves in each layer at the start of the experiment (upper panel) and after 3 wk

Fig. 4. Photosynthetic-irradiance (P-E) response curves in each layer at the start
of incubation (lower panels) almost identical (Fig. 4). The $E_{\mathrm{k}}$-value in the untreated ice dropped drastically from $>100$ in the top $10 \mathrm{~cm}$ to 67 below $10 \mathrm{~cm}$, but in the PAR and PAR+UVA treatments the values were $>100$ throughout the ice columns. All the surface ice communities expressed slight photoinhibition $(\beta, \mathrm{p}>0.05)$ after $4 \mathrm{~d}$ incubation (data not shown), but at the end of the experiment photoinhibition was not observed in the PAR treatment (Fig. 4).

\section{Bacterial responses}

The TTI and TLI rates in the untreated ice were always highest in the top $10 \mathrm{~cm}$, and usually in the top $5 \mathrm{~cm}$ (Fig. 2B,C). On average, in the treated ice, the exclusion of UVA enhanced the incorporation rates, whereas the exposure to UVA kept the rates at a significantly lower level, the difference between treatments being most pronounced in the top $5 \mathrm{~cm}$ (Table 1). In the surface ice layer of the PAR+UVA treatment, TTI rates were similar to those measured from the untreated ice, whereas TLI rates were lower than in both the untreated ice and the PAR treatment (Fig. 2B,C). TTI and TLI in whole ice columns of the treated and untreated ice were tightly coupled (Spearman's $\rho=$ 0.73 to $0.85, \mathrm{p}=0.01, \mathrm{n}=13$ and 16 , respectively) indicating balanced bacterial growth. However, in the top $5 \mathrm{~cm}$ layer, balanced growth was observed only in the PAR treatment (Spearman's $\rho=0.70$ UNT, $\rho=0.80$ PAR+UVA, $\rho=1.0$ PAR, $n=4$ to 5). The mean TLI:TTI ratio in the untreated ice column was slightly higher and varied more $(245 \pm 71)$ than in the treated ice (221 \pm 37 ). Because the ratios in untreated and treated ice were more or less identical in the layers below $5 \mathrm{~cm}$, the difference was mostly attributed to markedly different ratios the surface layer (Fig. 5). In the PAR+UVA treatment, the variation in the ratio was due more to ratio. During the first $2 \mathrm{wk}$, the ratio in untreated ice 


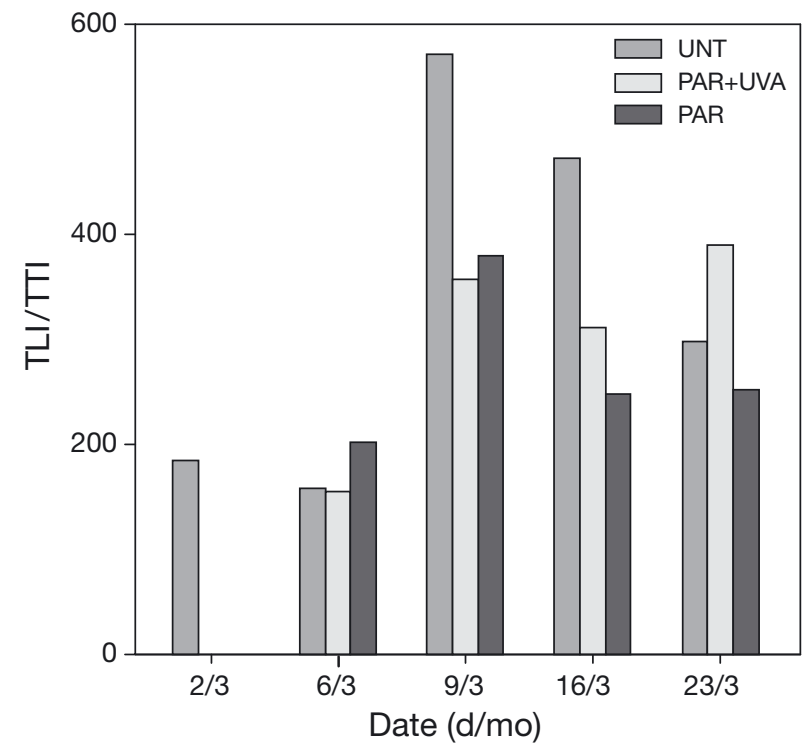

Fig. 5. Total ${ }^{14} \mathrm{C}$-leucine incorporation: total ${ }^{3} \mathrm{H}$-thymidine incorporation (TLI:TTI) ratio in the top $5 \mathrm{~cm}$ of untreated (UNT) and treated (PAR and PAR+UVA) ice

was due mostly to changes in TLI, similar to the PAR+UVA treatment; however, by the last sampling, TTI increased at double the rate of TLI.

TBN had the opposite distribution compared with incorporation rates and thus the highest TBN was observed in layers below $10 \mathrm{~cm}$ in the untreated ice. Exposure of the ice column to UVA resulted in slightly lower numbers (Fig. 2D), but the regression model fitted too poorly to reveal any significant differences (Table 1).

The incorporation rates in the untreated ice were closely linked to algal biomass (Spearman's $\rho=0.95$ TTI, $\rho=0.92$ TLI, $\mathrm{p}<0.01, \mathrm{n}=9$ ). In the PAR+UVA treatment, the relationship was equally strong with both TTI and TLI (Spearman's $\rho=0.89, \mathrm{p}<0.05, \mathrm{n}=6$ ), whereas in the PAR treatment TTI was linked to algal biomass (Spearman's $\rho=0.83, \mathrm{p}<0.05, \mathrm{n}=6$ ) but TLI was not (Spearman's $\rho=0.54, \mathrm{p}>0.05, \mathrm{n}=6$ ).

\section{DISCUSSION}

The dry snow efficiently reflects back the incident solar radiation, and the calculated albedos for dry snow cover from 5 to $20 \mathrm{~cm}$ thickness are very close to 1 (Perovich 1993). However, in the present study the untreated ice could not be used directly to assess the influence of snow cover on the effects of UVA, as the light spectrum above the untreated ice included UVB, of which some portion might have penetrated the snow cover. Thus, our observed results from untreated ice may be lower than they would be without UVB.

\section{The effects of UVA on algae}

The algal succession in the untreated ice was typical for Baltic Sea ice with a low-biomass, flagellate-dominated initial stage followed by increases in algal biomass and chl a concentration and the formation of distinct communities in the top and/or bottom of the sea ice due to the increased solar irradiation (Norrman \& Andersson 1994, Haecky \& Andersson 1999, Kaartokallio 2004, Rintala et al. 2006). In the present study, the lack of a high-biomass bottom community was most likely related to the low saline bottom layer, which had formed from the low saline water layer underlying the ice. The resulting low brine volumes are known to efficiently control the biomass in the Baltic Sea and to shift the community composition towards smaller species (Kaartokallio et al. 2007, Piiparinen et al. 2010, Rintala et al. 2010).

The removal of snow and exposure to the incident PAR led to a mean biomass that was one-third lower than that of the untreated ice. This biomass was even lower when UVA was included. Thus, it seems that snow cover provided some shelter for algae and the shelter was most likely related to light, as snow cover moderates the light spectrum and intensities in ice; however, the slightly different temperature regimes in the top $5 \mathrm{~cm}$ of the untreated and treated ice might have influenced the biomass as well. The lower chl a concentrations in the PAR treatment compared with untreated ice are explained better by the lower algal biomass and different community composition than by photoacclimation (i.e. the decrease in the chl a content of an algal cell as a response to increased light), as the chl a concentration in both the untreated ice and the PAR treatment were tightly coupled with algal biomass (Spearman's $\rho=0.90$ and 0.94, $\mathrm{p}<0.01, \mathrm{n}=9$ and 6 , respectively). In the PAR+UVA treatment, this connection was lost (Spearman's $\rho=0.60, \mathrm{p}>0.05, \mathrm{n}=6$ ), pointing to some UVA damage such as photobleaching (e.g. Maske \& Latasa 1997) or a switch from autotrophy to heterotrophy among the unidentified flagellated species.

The strong response of community composition to different light regimes revealed the UVA sensitivity of different algal groups and, in some cases, of different algal species. It must be noted that only a limited number of species was present in the initial community, and thus the results cannot be generalized too much. For example, the observed low dinoflagellate biomass, consisting of only one taxon, is in contradiction to earlier observations from the area (Kuosa \& Kaartokallio 2006, Rintala et al. 2006, Kaartokallio et al. 2007, Uusikivi et al. 2010). The most abundant group - small unidentified flagellates-seemed to be more sensitive to the incident PAR than to UVA. 
These flagellates belong to a variety of different algal groups and, thus, the species composition as well as their ratio of autotrophy to heterotrophy probably varied between samples. The increase in chlorophyte biomass with increasing PAR was not surprising, as chlorophytes generally grow better under higher irradiance (e.g. Richardson et al. 1983). In the Baltic Sea, chlorophytes do not generally form a major component of the sea-ice biota (Norrman \& Andersson 1994, Haecky \& Andersson 1999, Meiners et al. 2002, Kaartokallio et al. 2007, Rintala et al. 2010), and our results indicate that their growth in ice is linked to the amount of available PAR. However, their simultaneous demand for high PAR and apparent sensitivity to UVA act in opposite directions, narrowing their optimum environmental range and, thus, partly explaining why chlorophytes rarely form a significant biomass in sea ice. Pennate diatoms, in contrast to chlorophytes, are a common group in Baltic sea-ice communities, but their highest biomass is usually observed in the bottom layer of ice whereas centric species are encountered in the surface layers (Meiners et al. 2002, Kaartokallio et al. 2007, Piiparinen et al. 2010, Rintala et al. 2010). Our results revealed 2 interesting features of the 2 diatom groups. Firstly, despite their general preference for better-illuminated surface ice, the centric diatoms were clearly sensitive to the incident solar PAR in the absence of snow cover and Chaetoceros wighamii was the only centric species to survive under the UVA exposure. In contrast to the exposed ice, the biomass of centric diatoms in the untreated ice was highest in the top $5 \mathrm{~cm}$, which points to the beneficial role of snow cover in altering the quantity and quality of the incoming light closer to the optimum of the encountered centric diatoms. Secondly, the commonly observed vertical distribution of pennate diatoms within the ice column might be dictated more by UV radiation than their preference for low light levels. However, the dominant pennate species were unidentifiable and thus, this theory waits for further support. In freshwater, the benthic diatom communities, which generally consist of pennate species, were solely inhibited by UVA and no further reduction was observed with the addition of UVB (Bothwell et al. 1994). In the study of Karentz et al. (1991), the pennate diatom Nitzschia kerguelensis was the most UV-sensitive of the studied twelve Antarctic diatom species indicating that the typical 2-chloroplast configuration of pennate species might have played a role by not providing enough shelter for nucleic DNA.

In Antarctic phytoplankton, diatoms seem to be more resistant to solar UVR than flagellates, and the chl a synthesis of these communities is recovered from UVR exposure within a few days (Karentz 1994, Villafañe et al. 1995). In addition, according to the culture studies reviewed by Vernet (2000), green algae are generally as UVR-resistant as diatoms. These results are in contradiction with our results as, in terms of biomass, diatoms and chlorophytes were the most UVA-sensitive algal groups, and the chl a concentrations in the PAR+UVA treatment did not show any marked recovery. The production of screening compounds and the activation of the photorepair enzymes are light-inducible, and pre-acclimating the communities in PAR enhances the recovery from UV exposure compared with the non-acclimated communities. At a global scale, the different light regimes result in differences in the UV sensitivity between latitudes (Vernet 2000 and references therein). For example, Helbling et al. (1992) found that Antarctic phytoplankton was significantly more affected by UVR than tropical phytoplankton, and that more than $50 \%$ of the photoinhibition caused by UVR was due to UVA. In our experiment, the lack of pre-acclimation might have explained the poor recovery in the PAR+UVA treatment, as the darkacclimated algae generally show low tolerance to UVR. Uusikivi et al. (2010) measured high concentrations $\left(1.37 \pm 0.39 \mu \mathrm{g} \mathrm{l}^{-1}\right)$ of palythine and shinorine (MAAs) in the surface layer of snow-free ice in the same area in mid-March 2007. Thus, it cannot be ruled out that the exposure of algae to MAA synthesisinducing wavelengths (350 to $470 \mathrm{~nm}$ for diatoms) (Riegger \& Robinson 1997) might have triggered some MAA production in the PAR+UVA treatment.

The values of the photosynthetic parameters reflected the differences and changes in the community composition as well as the distance from the surface of the ice. The decline in light saturation index $\left(E_{\mathrm{k}}\right)$ with depth in the untreated ice is typical for snow-covered Baltic Sea ice (Piiparinen et al. 2010, Rintala et al. 2010), whereas the higher $E_{\mathrm{k}}$-values and lower $\alpha^{\mathrm{b}}$-values in the bottom layers of the treated ice indicated that sufficient amounts of light reached the bottom layer and that communities were less dark-adapted than in the untreated snow-covered ice. However, the $E_{\mathrm{k}}$-values in the snow-covered untreated ice were still well above those reported by Rintala et al. (2010) for sea-ice algae in Baltic Sea drift-ice $\left(39 \pm 27 \mu \mathrm{E} \mathrm{m}^{-2} \mathrm{~s}^{-1}\right)$, which might be because of the more southern location of our study area and the snow-ice layers in the Gulf of Bothnia (Rintala et al. 2010). The higher $\alpha^{\mathrm{b}}$ - and $P^{\mathrm{b}}{ }_{\mathrm{m}}$ values in the top $10 \mathrm{~cm}$ of the PAR+UVA treatment compared with the PAR treatment at the end of the experiment was most likely due to the different algal community composition in the treatments. The approximately equal $\alpha^{\mathrm{b}}$ - and $P_{\mathrm{m}}^{\mathrm{b}}$-values in the top $5 \mathrm{~cm}$ of the untreated ice and PAR+UVA treatment also indicate that the exposure to higher UVA irradiance did not affect the photosynthetic capacity and efficiency of the surviving community. 


\section{The effects of UVA on bacteria}

The incorporation rates and bacterial numbers in the untreated ice were within the range observed in earlier studies from the same area (Kaartokallio 2004, Kaartokallio et al. 2007). As expected, the effects of UVA on TTI, TLI and TBN were strongest in the top $5 \mathrm{~cm}$, and only occasionally occurred down to $10 \mathrm{~cm}$ depth. Therefore, the discussion below is focused on the top layer unless otherwise indicated.

The UVA-induced cell membrane damage affects the transport in and out of the cell (Jagger 1985). If the uptake of labelled thymidine and leucine are involved, an artificial uncoupling between the bacterial numbers and production rates would be observed (Sommaruga et al. 1997). In our experiment, the exposure to UVA did not result in any negative changes in the correlation between TBN and incorporation rates, either when all layers were included or when correlations were run only for the top $5 \mathrm{~cm}$. Thus, it can be concluded that this potential methodological drawback was insignificant for the present study.

Based on our results, UVA mainly affects bacterial production in Baltic Sea ice indirectly via algal biomass, and the differences in incorporation rates between the treatments were mostly due to differences in algal biomass and algal species composition. The stable algal biomass in the surface layer of the PAR+UVA treatment resulted in a stagnant period of 2 wk with a constant TTI rate, whereas in the PAR treatment the TTI rate started to increase with algal biomass, most of which was attributed to the growth of pennate diatoms and chlorophytes. The high TLI:TTI ratios found in the present study are typical for Baltic sea-ice bacterial communities (Mock et al. 1997, Kaartokallio et al. 2007). Besides unspecific incorporation of leucine to non-protein leucyl-tRNA (Chin-Leo \& Kirchman 1988), the high TLI may indicate a need for amino acids in, for example, osmoregulation (Mock et al. 1997, Kaartokallio et al. 2007). Our results indicate that one factor affecting the TLI rates besides algal biomass could be algal community composition, which affects the quantity and quality of exudated dissolved organic matter (DOM). The flagellate biomass in the clearly flagellate-dominated surface-ice communities of untreated ice and in the PAR+UVA treatment correlated significantly with TLI rates (Spearman's $\rho=1.0, \mathrm{n}=7$ ), whereas in the PAR treatment, where the algal species composition was different, no such connection could be found. According to Shiah \& Ducklow (1997), in less favourable conditions protein synthesis may be favoured for ensuring the survival of bacteria. This agrees with our results from the PAR+UVA treatment and untreated ice, where TTI remained stagnant but TLI had an increasing trend that was directly related to flagellate biomass. The decreasing TLI:TTI ratio in the PAR treatment after $1 \mathrm{wk}$ of incubation points to a switch from unfavourable to more favourable growth conditions (Shiah \& Ducklow 1997, Gasol et al. 1998), which could have been attributed to increased substrate supply from the increasing pennate diatom and chlorophyte biomass. However, the generally poor response in TBN to increase in TTI in the PAR treatment points to effective grazing or to other losses, such as viral control on bacteria in Baltic Sea ice, agreeing with earlier studies (Kaartokallio 2004, Kaartokallio et al. 2008).

UVA radiation could also have had direct effects on bacteria but, because of the strong influence of algal biomass on bacterial production, these effects were not obvious. Especially in the PAR+UVA treatment, the decline in algal biomass may have exposed the bacterial cells to UVA more than in the PAR treatment and untreated ice, where organisms might have protected each other from solar radiation by shading (e.g. Sommaruga et al. 1997). The mean UVA fluence rate (10 \pm $4.8 \mathrm{~W} \mathrm{~m}^{-2}$ ) during daytime in our study area in March (J. Uusikivi pers. comm.) is one-third of the UVA fluence rate used for studying sublethal oxidative damage to Escherichia coli (Pizarro 1995), and thus it can be assumed that the possible direct effects of UVA were mainly sublethal. The relatively stable TBN in the PAR+UVA treatment also points to the sublethal role of UVA. One of the sublethal effects of UVA is growth inhibition, which consists of growth delay and a subsequent small depression in growth rate (Jagger 1981). Growth inhibition is attributed to a decrease in RNA synthesis, which can be subsequently detected as reduced protein synthesis, but the studies reviewed by Jagger (1985) indicate that DNA damage is not involved. The incorporation rates in the bottommost layer were almost equal in the treatments and were markedly higher than in the untreated ice, which highlights the indirect effects of UVA via the primary producers.

\section{Climate change}

Model calculations of future ice conditions in the Baltic Sea predict milder winters, i.e. decreases in ice and snow thickness (Haapala et al. 2001, HELCOM 2007), which will allow more solar radiation to penetrate the ice cover. This radiation will include both UVB and UVA; therefore, our results concerning only UVA can be considered as the minimum effects of UVR on Baltic Sea sympagic communities.

The impact of natural intensities of UVA on bacteria was restricted to the top $5 \mathrm{~cm}$ of the ice, but the algal responses extended throughout the ice column. Extra- 
polating our results to future climate scenarios with more UVA in sea ice, we expect to see a decrease in ice-algal photosynthesis (i.e. $\mathrm{CO}_{2}$ fixation) and less autochthonous production available for the sympagic food web. If the algal species composition is altered and diversity is decreased in a manner similar to that in the present study, changes in trophic interactions in sea-ice food webs may be expected to occur (Karentz 1991), and the role of sea ice in seeding the algal spring bloom may be affected, both quantitatively and qualitatively. Although we did not observe any direct effects of UVA on bacteria, the indirect response attributed to algal biomass and algal species composition indicates that the reduced or qualitatively altered algal exudation of DOM will result in lower bacterial production rates, affecting the nutrient and energy fluxes in sea ice.

Acknowledgements. This study was funded by the Academy of Finland and the Walter and Andrée de Nottbeck Foundation. The help in the field of the staff at Tvärminne Zoological Station is gratefully acknowledged. We also thank our colleague J.-M. Rintala for providing the P-E data, and numerous people for the daily cleaning of the experimental units. The statistical guidance by R. Olsonen, revision and comments by R. Autio and anonymous reviewers are highly appreciated for improving this manuscript.

\section{LITERATURE CITED}

Aas P, Lyons MM, Pledger R, Mitchell DL, Jeffrey WH (1996) Inhibition of bacterial activities by solar radiation in nearshore waters and the Gulf of Mexico. Aquat Microb Ecol 11:229-238

Arrigo KR, Thomas DN (2004) Large scale importance of sea ice biology in the Southern Ocean. Antarct Sci 16:471-486

Asada K, Takahashi M (1987) Production and scavenging of active oxygen in photosynthesis. In: Kyle DJ, Osmond CB, Arntzen CJ (eds) Photoinhibition. Elsevier, Amsterdam, p 227-287

Bothwell ML, Sherbot DMJ, Pollock CM (1994) Ecosystem response to solar ultraviolet-B radiation: influence of trophic-level interactions. Science 265:97-100

Chin-Leo G, Kirchman DL (1988) Estimating bacterial production in marine waters from the simultaneous incorporation of thymidine and leucine. Appl Environ Microbiol 54:1934-1939

Draper NR, Smith H (1981) Applied regression analysis, 2nd edn. Wiley, New York, NY

> Ehn J, Granskog MA, Reinart A, Erm A (2004) Optical properties of melting landfast sea ice and underlying seawater in Santala Bay, Gulf of Finland. J Geophys Res 109, C09003 doi:10.1029/2003JC002042

Fuhrman JA, Azam F (1982) Thymidine incorporation as a measure of heterotrophic bacterioplankton production in marine surface waters: evaluation and field results. Mar Biol 66:109-120

Garcia-Pichel F (1994) A model for the internal self-shading in planktonic organisms and its implications for the usefulness of ultraviolet sunscreens. Limnol Oceanogr 39:1704-1717

Gasol JM, Davol MD, Pinhassi J, Calderón-Paz JI, GuixaBoixareu N, Vaqué D, Pedrós-Alió C (1998) Diel variations in bacterial heterotrophic activity and growth in the northwestern Mediterranean Sea. Mar Ecol Prog Ser 164: 107-124

> Granskog MA, Vihma T, Pirazzini R, Cheng B (2006) Superimposed ice formation and surface energy fluxes on sea ice during the spring melt-freeze period in the Baltic Sea. J Glaciol 52:119-127

Haapala J, Meier MHE, Rinne J (2001) Numerical investigations of future ice conditions in the Baltic Sea. Ambio 30: $237-244$

> Haecky P, Andersson A (1999) Primary and bacterial production in sea ice in the northern Baltic Sea. Aquat Microb Ecol 20:107-118

> Haecky P, Jonsson S, Andersson A (1998) Influence of sea ice on the composition of the spring phytoplankton bloom in the northern Baltic Sea. Polar Biol 20:1-8

Harm W (1980) Biological effects of ultraviolet radiation. Cambridge University Press, Cambridge

Helbling EW, Villafañe V, Ferrario M, Holm-Hansen O (1992) Impact of natural ultraviolet radiation on rates of photosynthesis and on specific marine phytoplankton species. Mar Ecol Prog Ser 80:89-100

Helbling EW, Marguet ER, Villafañe VE, Holm-Hansen O (1995) Bacterioplankton viability in Antarctic waters as affected by solar ultraviolet radiation. Mar Ecol Prog Ser 126:293-298

HELCOM (1988) Guidelines for the Baltic monitoring programme for the third stage; Part D. Biological determinants. Baltic Sea Environ Proc 27D:16-23

HELCOM (2006) Biovolumes and size-classes of phytoplankton in the Baltic Sea. Baltic Sea Environ Proc 106:1-142

HELCOM (2007) Climate change in the Baltic Sea area. Baltic Sea Environ Proc 111:1-49

> Hobbie JE, Daley RJ, Jasper S (1977) Use of Nuclepore filters for counting bacteria by fluorescence microscopy. Appl Environ Microbiol 33:1225-1228

Holm-Hansen O (1997) Short- and long-term effects of UVA and UVB on marine phytoplankton productivity. Photochem Photobiol 65:266-267

Jagger J (1981) Near-UV radiation effects on microorganisms. Photochem Photobiol 34:761-768

Jagger J (1985) Solar UV actions on living cells. Praeger Publishers, New York, NY

Jeffrey WH, Aas P, Lyons MM, Coffin RB, Pledger RJ, Mitchell DL (1996) Ambient solar radiation-induced photodamage in marine bacterioplankton. Photochem Photobiol 64:419-427

> Junge K, Imhoff F, Staley T, Deming JW (2002) Phylogenetic diversity of numerically important Arctic sea ice bacteria at subzero temperature. Microb Ecol 43:315-328

Kaartokallio H (2004) Food web components, and physical and chemical properties of Baltic Sea ice. Mar Ecol Prog Ser 273:49-63

> Kaartokallio H, Kuosa H, Thomas DN, Granskog MA, Kivi K (2007) Biomass, composition and activity of organism assemblages along a salinity gradient in sea ice subjected to river discharge in the Baltic Sea. Polar Biol 30:183-197

Kaartokallio H, Tuomainen J, Kuosa H, Kuparinen J, Martikainen PJ, Servomaa K (2008) Succession of sea-ice bacterial communities in the Baltic Sea fast ice. Polar Biol 31: 783-793

> Karentz D (1991) Ecological considerations of Antarctic ozone depletion. Antarct Sci 3:3-11

Karentz D (1994) Ultraviolet tolerance mechanisms in Antarctic marine organisms. In: Weiler CS, Penhale PA (eds) Ultraviolet radiation and biological research in Antarctica. American Geophysical Union, Washington, DC, p 93-110 
Karentz D, Cleaver JE, Mitchell DL (1991) Cell survival characteristics and molecular responses of Antarctic phytoplankton to ultraviolet-B radiation. J Phycol 27: 326-341

Karentz D, Bothwell ML, Coffin RB, Hanson A and others (1994) Impact of UV-B radiation on pelagic freshwater ecosystems: report of the working group on bacteria and phytoplankton. Arch Hydrobiol 43:31-69

Kirchman D, K'nees E, Hodson R (1985) Leucine incorporation and its potential as a measure of protein synthesis by bacteria in natural aquatic systems. Appl Environ Microbiol 49:599-607

Kuosa H, Kaartokallio H (2006) Experimental evidence on nutrient and substrate limitation of Baltic Sea sea-ice algae and bacteria. Hydrobiologia 554:1-10

Mälkki P, Tamsalu R (1985) Physical features of the Baltic Sea. Finn Mar Res 252:23-27

Martin A, Hall JA, O'Toole R, Davy SK, Ryan KG (2008) High single-cell metabolic activity in Antarctic sea ice bacteria. Aquat Microb Ecol 52:25-31

Maske H, Latasa M (1997) Solar ultraviolet radiation dependent decrease of particle light absorption and pigments in lake phytoplankton. Can J Fish Aquat Sci 54:697-704

Meiners K, Fehling J, Granskog MA, Spindler M (2002) Abundance, biomass and composition of biota in Baltic sea ice and underlying water (March 2000). Polar Biol 25: $761-770$

Menden-Deuer S, Lessard EJ (2000) Carbon to volume relationships for dinoflagellates, diatoms, and other protist plankton. Limnol Oceanogr 45:569-579

Mock T, Meiners KM, Giesenhagen HC (1997) Bacteria in sea ice and underlying brackish water at 54 $26^{\prime} 50^{\prime \prime} \mathrm{N}$ (Baltic Sea, Kiel Bight). Mar Ecol Prog Ser 158:23-40

Neftel A, Jacob P, Klockow D (1984) Measurements of hydrogen peroxide in polar ice samples. Nature 311:43-45

Norrman B, Andersson A (1994) Development of ice biota in a temperate sea area (Gulf of Bothnia). Polar Biol 14: 531-537

Peak MJ, Peak JG (1986) Molecular photobiology of UVA. In: Urbach F, Gange RW (eds) The biological effects of UVA radiation. Praeger Publishers, New York, NY, p 42-53

Perovich D (1993) A theoretical model of ultraviolet light transmission through Antarctic sea ice. J Geophys Res 98: 22579-22587

Perovich D (1998) The optical properties of sea ice. In: Leppäranta M (ed) Physics of ice covered seas, Vol. 1. Helsinki University Press, Helsinki, p 195-230

> Piiparinen J, Kuosa H, Rintala JM (2010) Winter-time ecology in the Bothnian Bay, Baltic Sea: nutrients and algae in fast ice. Polar Biol 33:1445-1461

Pirazzini R, Vihma T, Granskog MA, Cheng B (2006) Surface albedo measurements over sea ice in the Baltic Sea during the spring snowmelt period. Ann Glaciol 44:7-14

Pizarro RA (1995) UV-A oxidative damage modified by environmental conditions in Escherichia coli. Int J Radiat Biol 68:293-299

Platt T, Gallegos CL, Harrison WG (1980) Photoinhibition of photosynthesis in natural assemblages of marine phytoplankton. J Mar Res 38:687-701
Rasmus K, Ehn J, Granskog M, Kärkäs E and others (2002) Optical measurements of sea ice in the Gulf of Finland. Nord Hydrol 33:207-226

> Richardson K, Beardall J, Raven JA (1983) Adaptation of unicellular algae to irradiance: an analysis of strategies. New Phytol 93:157-191

> Riegger L, Robinson D (1997) Photoinduction of UV-absorbing compounds in Antarctic diatoms and Phaeocystis antarctica. Mar Ecol Prog Ser 160:13-25

Rintala JM, Piiparinen J, Ehn J, Autio R, Kuosa H (2006) Changes in phytoplankton biomass and nutrient quantities in sea ice as responses to light/dark manipulations during different phases of the Baltic winter 2003. Hydrobiologia 554:11-24

Rintala JM, Piiparinen J, Uusikivi J (2010) Drift-ice and under-ice water communities in the Gulf of Bothnia (Baltic Sea). Polar Biol 33:179-191

Roy S (2000) Strategies for the minimisation of UV-induced damage. In: de Mora S, Demers S, Vernet M (eds) The effects of UV radiation in the marine environment. Cambridge University Press, Cambridge, p 177-205

Ryan KG, McMinn A, Mitchell KA, Trenerry L (2002) Mycosporine-like amino acids in Antarctic sea ice algae, and their response to UVB radiation. Z Naturforsch C 57: 471-477

Salin ML (1988) Toxic oxygen species and protective systems of the chloroplast. Physiol Plant 72:681-689

Shiah FK, Ducklow HW (1997) Bacterioplankton growth responses to temperature and chlorophyll variations in estuaries measured by thymidine:leucine incorporation ratio. Aquat Microb Ecol 13:151-159

Simon M (1990) Improved assessment of bacterial production: combined measurements of protein synthesis via leucine and cell multiplication via thymidine incorporation. Arch Hydrobiol Beih Ergeb Limnol 34:151-155

Sommaruga R, Obernosterer I, Herndl GJ, Psenner R (1997) Inhibitory effect of solar radiation on thymidine and leucine incorporation by freshwater and marine bacterioplankton. Appl Environ Microbiol 63:4178-4184

Steemann Nielsen E (1952) The use of radioactive carbon (C14) for measuring organic production in the sea. J Cons Int Explor Mer 18:117-140

Utermöhl H (1958) Zur Vervollkommnung der quantitativen Phytoplankton-Methodik. Mitt Int Ver Theor Angew Limnol 9:1-38

Uusikivi J, Vähätalo AV, Granskog MA, Sommaruga R (2010) Contribution of mycosporine-like amino acids and colored dissolved and particulate matter to sea ice optical properties and ultraviolet attenuation. Limnol Oceanogr 55: 703-713

Vernet M (2000) Effects of UV radiation on the physiology and ecology of marine phytoplankton. In: de Mora S, Demers $S$, Vernet $M$ (eds) The effects of UV radiation in the marine environment. Cambridge University Press, Cambridge, p 237-278

Villafañe VE, Helbling EW, Holm-Hansen O, Chalker BE (1995) Acclimatization of Antarctic natural phytoplankton assemblages when exposed to solar ultraviolet radiation. J Plankton Res 17:2295-2306

Submitted: April 5, 2010; Accepted: December 27, 2010 Proofs received from author(s): March 1, 2011
Editorial responsibility: Gerhard Herndl, Vienna, Austria 